\title{
Improving Teaching and Learning in an Information Systems Subject: A Work in Progress
}

\author{
Lorraine J. Staehr and Graeme J. Byrne \\ School of Engineering and Mathematical Sciences, \\ Latrobe University, Bendigo, Victoria, Australia
}

l.staehr@latrobe.edu.au g.byrne@latrobe.edu.au

\begin{abstract}
The aim of this intervention was to include and evaluate the effect of teamwork on student learning outcomes in an information systems development subject. This was achieved by encouraging student peer learning through a small group team based approach that emphasized teamwork throughout the whole semester. Student evaluations confirmed that teamwork improved student learning outcomes.
\end{abstract}

Keywords: peer learning, information systems education, teamwork, teaching methods.

\section{Introduction}

This paper reports on an ongoing action research project that uses current educational theory and practice to improve the teaching and learning outcomes in an information systems development subject. This subject is taken by students in the second year of a three year Bachelor of Information Technology. The subject is taught in a small group teaching mode using experiential learning activities in an environment designed to encourage a deep approach to learning.

Students' approaches to learning can be broadly categorized as either surface or deep (Ramsden, 1992). Deep learning approaches focus on seeking the meaning of the subject content as a cohesive whole in contrast to surface learning approaches which focus on acquiring the knowledge associated with isolated facts. A consistent finding of many studies is that only deep approaches are likely to lead to conceptually significant learning (Prosser \&Trigwell, 1999).

The teaching method in this subject incorporates the following features to encourage students to take a deep approach to their learning:

- $\quad$ setting explicit and clear goals for student learning on a weekly basis,

- assessment tasks that require a deep approach to learning,

- activities that teach students how to learn,

- experiential learning activities,

Material published as part of this publication, either on-line or in print, is copyrighted by the Informing Science Institute. Permission to make digital or paper copy of part or all of these works for personal or classroom use is granted without fee provided that the copies are not made or distributed for profit or commercial advantage AND that copies 1) bear this notice in full and 2) give the full citation on the first page. It is permissible to abstract these works so long as credit is given. To copy in all other cases or to republish or to post on a server or to redistribute to lists requires specific permission and payment of a fee. Contact Publisher@InformingScience.org to request redistribution permission.
- $\quad$ exposure to variation through making other students' ideas available. The full details of this approach are reported in Cope and Staehr (2005).

The intervention described in this paper built on the existing approach described above. The overall aim was to extend the learning experience to include the following aspects described by Moore, O'Rourke \& Powell (2007, p. 1), where 
Improving Teaching and Learning in an IS Subject

students "develop professional and personal skills as well as attributes ranging from teamwork and leadership skills to problem solving and information literacy. They can also develop attitudes such as acceptance of responsibility for their own learning and actions." Specifically, it was hoped that the implementation of teamwork in the subject would

- Develop skills valued in the work place (e.g. problem solving, planning, managing projects and meetings, communication skills, leadership skills, time management, information literacy, presentation and organizational skills)

- Establish student learning communities (i.e. peer learning)

- Increase student engagement in the subject.

These are all part of a set of skills that assist students to become lifelong learners. The aim was to move students from dependence (on the lecturer) towards independence and interdependence in learning (Boud, 2001). An important component of the intervention was its evaluation which is discussed in the Method section of the paper.

The educational benefits of teamwork, peer learning, and student engagement are well documented in the education literature (e.g. Boud, Cohen, \& Sampson, 2001a; Harper \& Quaye, 2009; Wells, 2002)). In the workplace few IT professionals work in isolation but are more likely to work in a project team environment. The ACM/IEEE model curricula for computer science and information technology (Cassel et al., 2008; Lunt et al., 2008), and the draft ACM/IS model curricula for information systems (Topi et al., 2009), all acknowledge teamwork skills as an important graduate attribute. There is also evidence that not only IT employers but employers in general value teamwork skills (Employability skills, 2002; Fernandez-Sanz, 2009; Hager \& Holland, 2006). Therefore, the inclusion of a teamwork component in an information systems development subject is well justified.

Most previously reported research on teamwork in computer science and information systems subjects (e.g. Bieliková \& Návrat, 2005; Wells, 2002) involves students developing a software product in teams in a capstone subject that attempts to simulate the team environment in the IT industry. In contrast this intervention involved a traditional content-oriented subject that included a syllabus of individual information systems development topics. This paper responds to the call from Martin (2007) who denounces a "one shot" approach to teamwork. She suggests that teamwork should be incorporated in all subjects across the curriculum to adequately prepare students for IT professional roles.

\section{Method}

This section of the paper has three parts. It outlines the intervention, followed by the quantitative and the qualitative evaluation methods.

\section{The Intervention}

Although a small group teaching approach was in place before the intervention, students were not required to work in the same group throughout the semester, nor were they required to complete a team assignment. These were two of the changes that were implemented. In addition there was a move towards enquiry based learning for some tasks. A summary of the main changes are shown in Table 1. These changes are explained in detail below. 
Table 1: Summary of the changes

\begin{tabular}{|l|l|l|}
\hline Characteristics & \multicolumn{1}{|c|}{ Before intervention } & \multicolumn{1}{c|}{ Intervention } \\
\hline $\begin{array}{l}\text { Allocation to } \\
\text { groups }\end{array}$ & Self selected & $\begin{array}{l}\text { Students allocated by lecturer ensuring di- } \\
\text { versity in academic ability, gender and lo- } \\
\text { cal/international student mix in each team }\end{array}$ \\
\hline Team building & None & $\begin{array}{l}\text { Team building exercises early in the semes- } \\
\text { ter. Preparation of a team charter and a } \\
\text { non-assessed exercise to get the team work- } \\
\text { ing together from the start }\end{array}$ \\
\hline Group work & $\begin{array}{l}\text { Since self selected could be different } \\
\text { combinations of students for each } \\
\text { weekly experiential classroom activity } \\
\text { throughout the semester }\end{array}$ & $\begin{array}{l}\text { Students completed all weekly experiential } \\
\text { classroom activities throughout the semes- } \\
\text { ter in their allocated team }\end{array}$ \\
\hline Assignments & Two individual assignments & $\begin{array}{l}\text { Substantial component of one assignment } \\
\text { involved team work (20\% of final grade) }\end{array}$ \\
\hline
\end{tabular}

Students were assigned to a team at the start of the semester and remained in this team for the whole semester. Students were allocated to teams in the following ways. Academic ability was taken into account and the students were allocated so that teams were similar in this respect e.g. at least one high achieving student, based on university entrance scores. In this cohort there were several international students and only a few female students. International students were dispersed throughout the teams and female students were allocated to teams so that there was a minimum of two female students in a team. There were six teams with between four and six students in each team i.e. 28 students. Consistency of numbers in teams was difficult to arrange at the start of the semester with students withdrawing from the subject, students enrolled but not appearing, or new students arriving.

The initial team exercises were the preparation of a team charter and investigation of a topic by the team to be presented to the rest of the class. The team charter involved the development of an escutcheon for the team (to introduce some fun), a record of team contact details, agreed meeting times, team rules and expectations, and a code of ethics. The team charter was an assessable piece of work. Teams were given team meeting templates to indicate how meetings should be organized and documented. However the use of this template was not checked or assessed. The topic for the team presentation was IT project success and failure since IT project management was an important part of the subject content. The presentation was not assessed. Its purpose was to get students working together early as a team, using the library sources, and to provide feedback on presentations so they would have an opportunity to improve for another presentation that would be assessed later in the semester.

For all weekly experiential learning activities throughout the semester the students worked in their allocated teams. It was hoped that they would form learning communities and that peer learning would occur. In addition, three of the four parts of one assignment in the subject required teamwork. These were the preparation and documentation of the team charter (described above), then later in the semester, a team presentation to the rest of the class on quality assurance in software development, and a project management plan (related to a case study used throughout the semester). Overall team assignments accounted for $20 \%$ of the assessment in the subject. This weighting for team assignments is the minimum recommended for students to perceive an assessment as valuable (Boud, Cohen, \& Sampson, 2001b). 
Improving Teaching and Learning in an IS Subject

\section{Quantitative Evaluation}

The sample of students in this study was not a random sample but a convenience sample. They were students enrolled in the second year subject Information Systems Development in a three year Bachelor of Information Technology degree program in the Department of Computer Science and Computer Engineering at La Trobe University. In the last week of the semester a questionnaire was administered by a person other than the subject lecturer. The questionnaire responses were anonymous. Twenty one students completed the questionnaire. They varied in age from nineteen to forty one years (mean 22.8 years, median 20.5 years). Five of the 21 students were female.

The questionnaire was adapted from the draft Student Enquiry Based Learning (EBL) Survey (Moore, 2006). The quantitative part of the adapted questionnaire consisted of 37, five point, Likert scale questions. The main way the questionnaire was adapted was to change the focus of the questionnaire from evaluating a single activity to evaluating the whole subject. It should be noted that this is not a validated questionnaire.

\section{Qualitative Evaluation}

There were three different ways of assessing the intervention qualitatively. The first consisted of student answers to the open ended questions from the draft Student EBL Survey (Moore 2006). This survey was considered suitable since although not involving true enquiry based learning the subject contained many of the elements of enquiry based learning e.g. teamwork, peer learning in classroom sessions and assignment work. The second involved the lecturer writing a reflective diary throughout the semester. At the end of each week during the semester the lecturer recorded observations about student reactions to the work that week and any ideas for improvements for next year. And third, each student completed a self and peer assessment as part of the team assignment. (Note that marks were allocated to this part of the assignment to encourage thoughtful responses).

\section{Results and Discussion}

The results of the evaluations are reported and discussed in two sections below. The first section reports on the quantitative results and the second part reports on the qualitative results.

\section{Quantitative}

It was possible to group some of the Likert scale questions into five composite measures organized by the question content. The following composites were identified:

- presenting findings i.e. a perceived improvement in ability to make oral presentations and present findings well,

- independent learning i.e. a perceived improvement in ability to take responsibility for learning,

- teamwork i.e. a perceived improvement in teamwork skills, including leadership skills, developing shared goals, solving any issues, contributing to team goals,

- information literacy i.e. a perceived ability to better find and evaluate information,

- deep learning i.e. a perception that the subject was not simply about memorizing facts.

Estimates of internal consistency (alpha coefficients) for each composite were calculated and are shown in Table 2. A Cronbach alpha of 0.7 is thought to demonstrate good construct reliability (De Vries, 1990) although some authors report values as low as 0.5 to be satisfactory (Laukkanean, Halonen,\& Viinamaki, 1999). The estimates for four of the composites indicate good 
construct reliability and although the estimate for 'deep learning' is not as high as we would like, it is still acceptable.

Table 2: Cronbach alphas for composites

\begin{tabular}{|l|l|l|l|}
\hline \multicolumn{1}{|c|}{ Composite } & $\begin{array}{l}\text { Number of } \\
\text { questions }\end{array}$ & $\begin{array}{c}\text { Sample } \\
\text { size }\end{array}$ & $\begin{array}{c}\text { Cronbach } \\
\text { alpha }\end{array}$ \\
\hline $\begin{array}{l}\text { Presenting } \\
\text { findings }\end{array}$ & 4 & 21 & 0.843 \\
\hline $\begin{array}{l}\text { Independent } \\
\text { learning }\end{array}$ & 5 & 20 & 0.709 \\
\hline Teamwork & 11 & 18 & 0.858 \\
\hline $\begin{array}{l}\text { Information } \\
\text { literacy }\end{array}$ & 3 & 21 & 0.883 \\
\hline Deep learning & 4 & 20 & 0.594 \\
\hline
\end{tabular}

The composites were analyzed according to gender. The means and standard errors of the composites for males and females are shown in Table 3. A multivariate test (Wilks' Lambda) was used to simultaneously test male versus female contrasts for the five composites. This test revealed no statistically significant differences $(p=0.209)$ between males and females for any of the mean composite scores. Although univariate t-tests did reveal a significant difference $(p=$ 0.024 ) between males and females on the information literacy mean score, it would be imprudent to claim that this was statistically significant given the result of the multivariate test above.

\begin{tabular}{|l|c|c|}
\hline \multicolumn{3}{|c|}{ Table 3: Means of composites } \\
by gender (standard errors in parentheses) \\
\hline \multicolumn{1}{|c|}{ Composite } & Male Mean & Female Mean \\
\hline Presenting findings & $3.33(0.227)$ & $3.85(0.281)$ \\
\hline Independent learning & $3.69(0.173)$ & $3.73(0.213)$ \\
\hline Teamwork & $3.11(0.178)$ & $3.34(0.394)$ \\
\hline Information literacy & $3.04(0.199)$ & $4.07(0.400)$ \\
\hline Deep learning & $3.63(0.134)$ & $3.45(0.619)$ \\
\hline
\end{tabular}

Therefore, although the perceived ability to find and evaluate information appears to be higher for females than for males when considered alone, the multivariate result must take precedence and we conclude that there was no statistically significant gender effect on any of the composite scores.

Figures 1 and 2 show scatter plots of 'presenting findings' against 'teamwork' and 'independent learning against 'teamwork'. When the student perceived that they had an improved ability to present findings they also scored teamwork highly. A group presentation was one of the assessable team tasks. Therefore, as we would expect, students' perceptions about working in a team to prepare a group presentation is positively related to the perceived teamwork skills developed in this study. At first glance, a high score on improved capacity for 'independent learning' and a high score for teamwork seems incongruous. However, since teams allocate tasks to individuals at least when work is initially started, students may work independently before submitting work to the team for review and revision. Having their work valued by the team may foster a greater capacity for independent learning. However, it should be noted that there is a tendency in self reporting questionnaires for participants who score one question highly to score others highly. 
Since the questions that made up each of the composites were interspersed throughout the questionnaire this effect was probably small in this study.

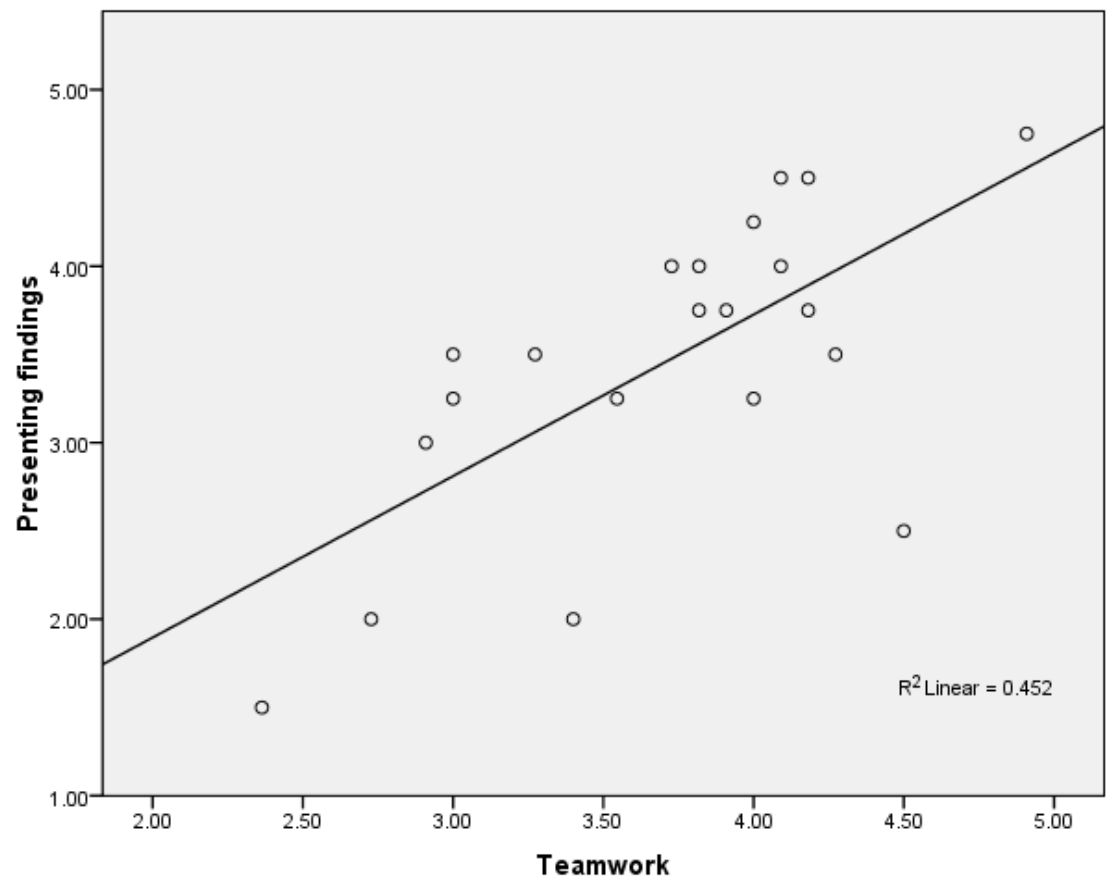

Figure 1: The relationship between 'Presenting findings' and 'Teamwork'

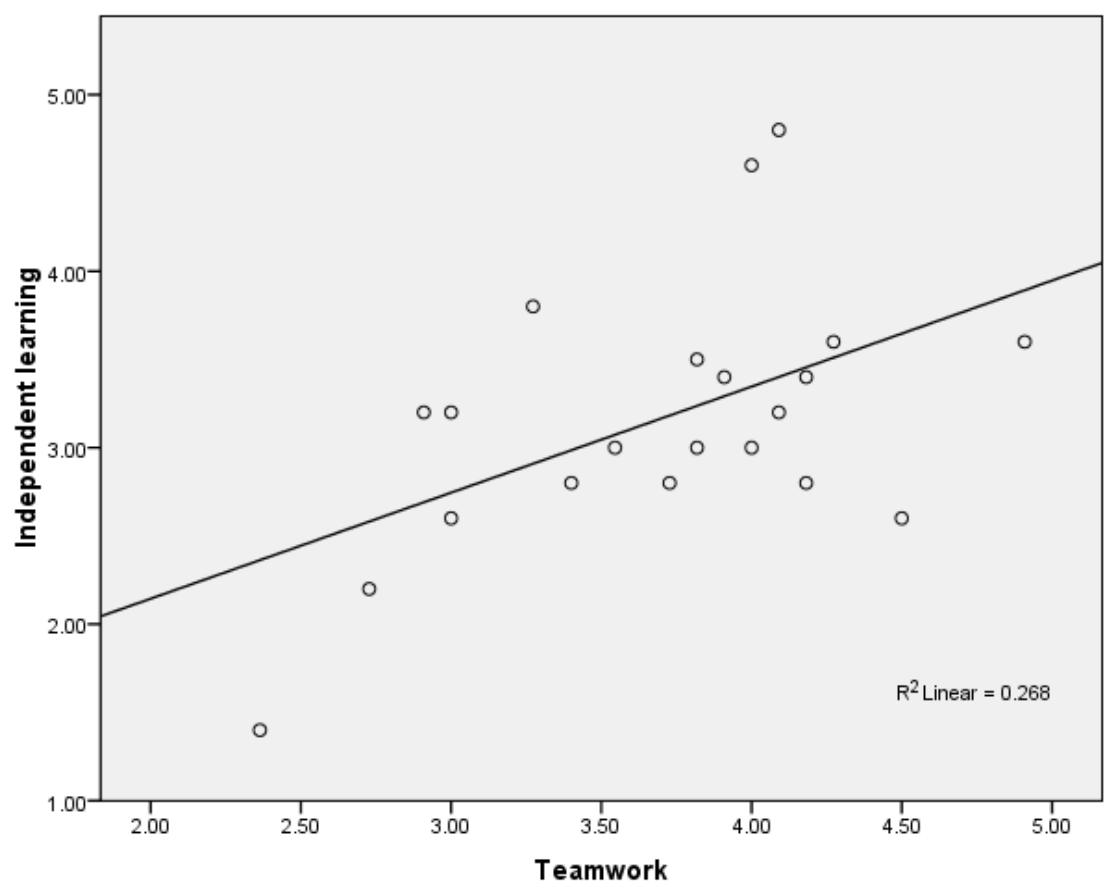

Figure 2: The relationship between 'Independent learning' and 'Teamwork' 
In order to explore the relationships between the composites further, correlation coefficients were calculated and are shown in Table 4. All of the composites except 'deep learning' were positively correlated with 'teamwork'. It is not surprising that 'independent learning', 'presenting findings' and 'information literacy' are all highly correlated with 'teamwork' since the team exercises and assignments provided the opportunity for students to improve in all of these areas. The 'deep learning' composite appears to be unrelated to the other four composites. All of the assessment tasks in the subject, both individual and team, are designed to encourage students to individually take a deep approach to their learning. It therefore seems reasonable that it was not found to be correlated to the other composites which required a team approach.

\begin{tabular}{|c|c|c|c|c|c|c|}
\hline \multirow{2}{*}{\multicolumn{7}{|c|}{$\begin{array}{l}\text { Table 4: Correlation coefficients for the composites } \\
\text { "Correlation is significant at the } 0.05 \text { level } \\
{ }^{* 4} \text { Correlation is significant at the } 0.01 \text { level }\end{array}$}} \\
\hline & & & & & & \\
\hline & & Teamwork & $\begin{array}{l}\text { Independent } \\
\text { learning }\end{array}$ & $\begin{array}{l}\text { Presenting } \\
\text { findings }\end{array}$ & $\begin{array}{c}\text { Information } \\
\text { literacy }\end{array}$ & $\begin{array}{c}\text { Deep } \\
\text { learning }\end{array}$ \\
\hline Teamwork & $\begin{array}{l}\text { Pearson } \\
\text { Sig. } \\
\text { N }\end{array}$ & 1 & $\begin{array}{r}.517^{*} \\
.016 \\
21\end{array}$ & $\begin{array}{r}.673^{* *} \\
.001 \\
21\end{array}$ & $\begin{array}{r}.599^{* * *} \\
.004 \\
21\end{array}$ & $\begin{array}{r}.208 \\
.365 \\
21\end{array}$ \\
\hline Independent learning & $\begin{array}{l}\text { Pearson } \\
\text { Sig. } \\
\text { N }\end{array}$ & & 1 & $\begin{array}{r}.716^{* *} \\
.000 \\
21\end{array}$ & $\begin{array}{r}.506^{*} \\
.019 \\
21\end{array}$ & $\begin{array}{r}.425 \\
.055 \\
21\end{array}$ \\
\hline Presenting findings & $\begin{array}{l}\text { Pearson } \\
\text { Sig. } \\
\text { N }\end{array}$ & & & 1 & $\begin{array}{r}.740^{* *} \\
.000 \\
21\end{array}$ & $\begin{array}{r}.110 \\
.634 \\
21\end{array}$ \\
\hline Information literacy & $\begin{array}{l}\text { Pearson } \\
\text { Sig. } \\
\text { N }\end{array}$ & & & & 1 & $\begin{array}{r}-.019 \\
.934 \\
21\end{array}$ \\
\hline Deep learning & $\begin{array}{l}\text { Pearson } \\
\text { Sig. } \\
\text { N }\end{array}$ & & & & & 1 \\
\hline
\end{tabular}

\section{Qualitative}

Results from analysis of the open ended questions from the adapted draft Student EBL Survey (Moore, 2006) are shown in Table 5. The table contains actual student quotes from the questionnaires. Where there were similar quotes from other students there is a number in brackets following the quote. This number indicates how many students made similar comments. A summary of the quotes for each statement is given below:

Statement1: A number of students reported that it was helpful working in a team. The comment about the group sharing understandings can be interpreted as an indicator of peer learning.

Statement2: The students reported group work, independent learning, presentation skills, communication skills and planning skills as the most useful things/skills learnt. How hard it is to work in a group is mentioned by one student indicating that there were issues in at least one group.

Statement 3: The reported influences that changed the way students learned were primarily teamwork and independent learning.

Statement 4: Students perceived that learning was made more effective in a variety of ways. These were through teamwork, independent learning, self imposed peer pressure and assessments that encouraged students to work consistently throughout the semester. 
Statement 5: Students mainly found teamwork and adapting to independent learning the most difficult aspects of the subject.

\begin{tabular}{|c|c|}
\hline \multicolumn{2}{|c|}{ Table 5: Sample qualitative responses } \\
\hline Statement & Student Quote \\
\hline 1. The thing I found most helpful was... & $\begin{array}{l}\text { "Being able to get help from group members" (3) } \\
\text { "Working in a group to share understandings" } \\
\text { "Working in a team" (9) } \\
\text { "Being in a GOOD team" } \\
\text { "Doing things as a member and combined them } \\
\text { later as a team" } \\
\text { "The textbook" } \\
\text { "The workshops" }\end{array}$ \\
\hline $\begin{array}{l}\text { 2. The most useful thing/skill I learned } \\
\text { was... }\end{array}$ & $\begin{array}{l}\text { "Working in a group" (5) } \\
\text { "Communication" } \\
\text { "How hard it is to work in a group situation" } \\
\text { "Planning" } \\
\text { "How to give presentation in professional way" (2) } \\
\text { "Group working, self learning and planning for } \\
\text { studying" } \\
\text { "How to teach myself how to do the tasks required } \\
\text { for the subject" }\end{array}$ \\
\hline $\begin{array}{l}\text { 3. The thing that was different about this } \\
\text { subject and most changed the way I } \\
\text { learned was... }\end{array}$ & $\begin{array}{l}\text { "Working in a group" (4) } \\
\text { "How everything we learnt was more self taught } \\
\text { than lectured from the teacher" (6) } \\
\text { "Planning" } \\
\text { "Working in a group but do your own part of the } \\
\text { work" } \\
\text { "That I had to read about the [weekly topic] before } \\
\text { I go to the workshop" } \\
\text { "The teacher was deliberately vague, making us do } \\
\text { more research than I normally would have" }\end{array}$ \\
\hline $\begin{array}{l}\text { 4. What made learning most effective for } \\
\text { me was... }\end{array}$ & $\begin{array}{l}\text { "Working as a group" (5) } \\
\text { "Learning from my group" } \\
\text { "Learning individually" } \\
\text { "Tutorial marking sessions" (2) } \\
\text { "Reading before the lecturer speaks about the sub- } \\
\text { ject" } \\
\text { "Constant assessments throughout the semester" } \\
\text { "My progress could affect others" }\end{array}$ \\
\hline 5. The thing I found most difficult was... & $\begin{array}{l}\text { "Working in a group of people who have different } \\
\text { goals" } \\
\text { "Working in a group" (3) } \\
\text { "Group assignments" } \\
\text { "Making notes on all readings before workshops as } \\
\text { well as assignments" } \\
\text { "To adapt to the way of independent study" (9) }\end{array}$ \\
\hline
\end{tabular}

The qualitative results indicate that the students felt that they gained some of the work place skills that the intervention was designed to develop. Students not only reported teamwork helpful but also found it an effective way of learning. For some students it was the most important skill learned. However it was obvious in the student responses that not all teams worked equally well 
and that some students found working in a team difficult. This is not surprising and has been reported elsewhere (e.g. Livingstone \& Lynch, 2000). Planning, presentation and communication skills were also mentioned as learning outcomes.

A number of student comments indicated that peer learning occurred as a result of the teamwork required in the subject. Comments such as "learning from the group", "sharing understandings" and "help from group members" provide evidence of student negotiation and construction of meaning with others (Coates, 2006, p.145). Rather than passively "receiving" information as might be the case in a lecture format students are interacting with the material and with other students. However, unfortunately it is not possible to estimate how widespread and how effective this peer learning was in the subject.

During the semester the lecturer kept a reflective diary. The most interesting observation was the increase in student engagement in group work observed over the whole semester. For one workshop in week 8 of the semester several student teams continued working beyond the allocated class time. This had never been observed in the previous ten years of group work in this subject. This increase in student engagement was a very pleasing outcome of the intervention. According to Coates (2006 p.145) this type of engagement indicates that students are having successful conversations about their learning and are developing knowledge.

The confidential peer and self assessment part of one of the assignments gave some interesting insights into how the teams functioned. Some students were more truthful about the contributions of their peers and themselves, than others. The small class size made it relatively easy to assess the accuracy of the self and peer assessments. Two of the teams functioned well but the other four teams had difficulties with at least one member who did not participate or contribute enough to the group effort.

Since this study was conducted at one university in a class with small student numbers it has limited external validity. However this cohort is similar to past cohorts and so some extrapolation to future cohorts is justified. It also must be remembered too that the questionnaire involved self reporting which can lead to respondent bias if students do not give considered answers or adopt a "yea or nay saying" approach. There was no evidence of the latter problem and the qualitative responses indicate a thoughtful approach by students. Also the five composite measures showed good internal consistency according to their Cronbach alpha estimates and there was an expected positive correlation between the four composites 'presenting findings', 'independent learning', information literacy' and 'teamwork'.

This study was a pilot and will be improved in the future through an action research cycle. For example, it is thought that in the next cycle students might benefit from more "fun" team exercises and some formal work on how teams function early in the semester. It would also be useful to conduct a much larger study to validate the composites developed from the quantitative part of the questionnaire (Moore, 2006). This would provide a validated questionnaire that could be used in similar future studies.

\section{Conclusion}

Five composites measures were identified by grouping the question content from the draft Student Enquiry Based Learning (EBL) Survey (Moore, 2006). They were 'Presenting findings', 'Independent learning, 'Teamwork', 'Information literacy' and 'Deep learning'. They were then tested for internal consistency using Cronbach alpha. Except for the 'Deep learning' composite, the alpha values were all above the recommended minimum, indicating that our choice of composites was reasonable. Although it would have been better to have used confirmatory factor analysis to validate the composite measures, this was not practical due to the rather small sample 
Improving Teaching and Learning in an IS Subject

size $(\mathrm{n}=21)$. In future work with a larger sample size, we expect the composites to be validated using more powerful techniques such as confirmatory factor analysis.

Despite some teams having problems, the quantitative and qualitative results together indicate that the intervention had a positive influence on student learning outcomes. Therefore it is considered that intervention was useful and improved the learning environment. Qualitative and quantitative results indicated that students perceived improvements in planning, communication skills, teamwork skills, independent learning, and peer learning. In addition increased student engagement in the subject was observed. These positive results provide an impetus to continue with the intervention in this subject in the future.

\section{Acknowledgements}

This study was supported financially by a La Trobe University Enquiry Based Learning/Student Peer Mentoring Pilot Project Grant.

\section{References}

Bieliková, M., \& Návrat, P. (2005) Experiences with designing a team project module for teaching teamwork to students. Journal of Computing and Information Technology, 13(1), 1-10.

Boud, D. (2001). Introduction: Making the move to peer learning. In D. Boud, R. Cohen \& J. Sampson (Eds.), Peer learning in higher education (pp. 1-17). London: Kogan Page.

Boud, D., Cohen, R., \& Sampson, J. (Eds.). (2001a). Peer learning in higher education. London: Kogan Page.

Boud, D., Cohen, R. \& Sampson, J. (2001b). Peer learning and assessment. In D. Boud, R. Cohen \& J. Sampson (Eds.), Peer learning in higher education (pp. 67-81). London: Kogan Page.

Cassel, L., Clements, A., Davies, G., Guzdial, M., McCauley, R. McGettrick, A., et al. (2008). Computer science curriculum 2008. Association for Computing Machinery (ACM)/IEEE Computer Society. Retrieved December 10, 2009, from http://www.computer.org/portal/cms docs ieeecs/ieeecs/education/cc2001/ComputerScience2008.pdf

Coates, H. (2006). Student engagement in campus-based and online education. Oxon: Routledge.

Cope, C., \& Staehr, L. (2005). Improving students' learning approaches through intervention in an information systems learning environment. Studies in Higher Education, 30(2), 181-198.

De Vries, D. (1990). Surveys in social research (2nd ed.), Sydney: Allen and Unwyn.

Employability skills: An employer perspective (2002). ACCI Review No. 88. Australian Chamber of Commerce and Industry.Retrieved December 15, 2009, from http://www.acci.asn.au/text files/issues_papers/Employ_Educ/ee21.pdf

Fernandez-Sanz, L. (2009). Personal skills for computing professionals. IEEE Computer, 42(10), 110-111.

Hager, P., \& Holland, S. (Eds.) (2006). Graduate attributes, learning and employability. Netherlands, Springer.

Harper, S., \& Quaye, S. (Eds.) (2009). Student engagement in higher education. New York: Routledge.

Laukkanean, E., Halonen, P., \& Viinamaki, H. (1999). Stability and internal consistency of the offer selfimage questionnaire: A study of Finnish students. Journal of Youth and Adolescence, 28, 71-77.

Livingstone, D., \& Lynch, K. (2000). Group project work and student-centred active learning two different experiences. Studies in Higher Education, 25(3), 325-345.

Lunt, B., Ekstrom, J., Gorka, S., Hislop, G., Kamali,R., Lawson, E., et al. (2008). Curriculum guidelines for undergraduate degree programs in information technology. Association for Computing Machinery 
(ACM)/IEEE Computer Society, Retrieved December 10, 2009, from http://www.acm.org//education/curricula/IT2008\%20Curriculum.pdf

Martin, C. D. (2007). Leadership, teamwork, and ethics in the development of IT professionals. SIGCSE Bulletin, 39(2), 8-9.

Moore, I. (2006). Draft student EBL survey. Retrieved December 10, 2009, from http://www.manchester.ac.uk/ceebl/resources/evaluation/evaluation_survey.rtf

Moore, I., O'Rourke, K. \& Powell, N. J. (2007). The enquiring mind knows no bounds: Does teaching across the disciplines have to be so different? Improving Student Learning - For What? In C. Rust (Ed.), The 15th Improving Student Learning Symposium, Trinity College, Dublin, Ireland.

Prosser, M., \& Trigwell, K. (1999). Understanding learning and teaching: The experience in higher education. Buckingham: Open University Press.

Ramsden, P. (1992). Learning to teach in higher education. London: Routledge.

Topi, H., Valacich, K., Kaiser, K., Nunamaker, J., Sipior, J, Vreede, G., et al. (2009). Draft curriculum guidelines for undergraduate degree programs in information systems. Association for Computing Machinery and Association for Information Systems, Retrieved December 10, 2009, from http://cis.bentley.edu/htopi/IS2009_09-11-2009.pdf

Wells, C. (2002). Teaching teamwork in information systems. In E. Cohen (Ed.), Challenges of IT education in the $21^{s t}$ century (pp. 1-24). Hershey, PA: Idea Publishing Group.

\section{Biographies}

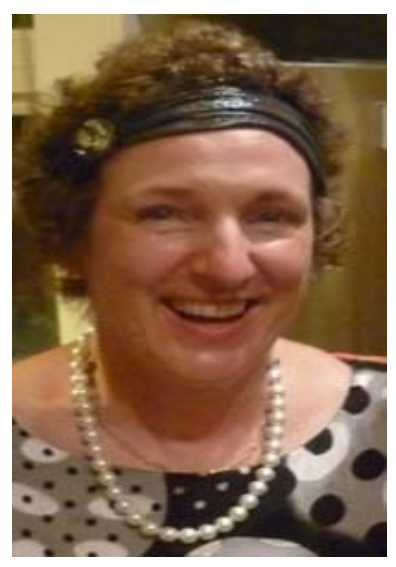

Lorraine Staehr is a Senior Lecturer in the Department of Computer Science and Computer Engineering at La Trobe University. Her research interests are in the adoption and impact of IT in organisations, government and the community, gender and IT, and information systems education. She has published research papers in international conferences and journals, including the International Conference on Information Systems and the Information Systems Journal.

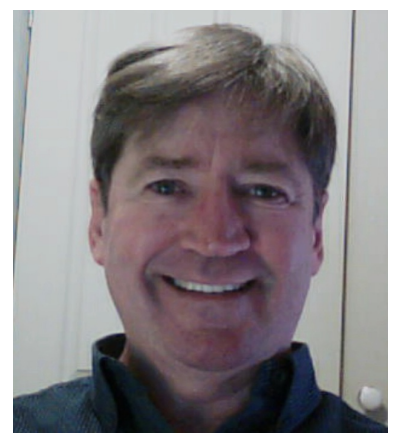

Graeme Byrne is a Senior Lecturer in the Department of Mathematics at La Trobe University. He has taught in a wide variety of mathematical and statistical areas. His academic research interests revolve around approximation theory, statistical computing and analysis, experimental design, educational research, demographics and marketing research. 